\title{
PREVALENCE OF HUMAN PAPILLOMAVIRUS INFECTION IN RURAL VILLAGES OF THE BOLIVIAN AMAZON
}

\begin{abstract}
Jorge CERVANTES(1), Carolina LEMA(2), Luisa HURTADO(2), Ronald ANDRADE(2), Gladys QUIROGA(2), Giovanni GARCIA(2), Lorena TORRICOS(2), Lourdes ZEGARRA(2), Veronica VERA(2), Wilge PANOSO(3), Rosario ARTEAGA(4), David SEGURONDO(4), Fernando ROMERO(4), Alfredo DULON(4), David ASTURIZAGA(4), Luis HURTADO GOMEZ(5) \& Shunro SONODA ${ }^{1,6}$
\end{abstract}

\begin{abstract}
SUMMARY
Cervical cancer constitutes a major health problem in developing countries like Bolivia. The roles of certain genotypes of human papillomaviruses (HPVs) in the pathogenesis of cervical cancer is well established. The prevalence of HPV infection among sexually active women varies greatly. Information regarding HPV infection in Bolivia is very much scarce, specially in regions like the Amazonian lowland.

We studied 135 healthy women living in four rural localities of the Bolivian Amazon. Presence of HPV in DNA extracted from cervical swabs was analyzed using a reverse line hybridization assay. The estimated overall HPV infection prevalence among the studied rural localities was $5.9 \%$ (ranging from $0-16.6 \%$ ). These values were unexpectedly low considering Bolivia has a high incidence of cervical cancer.
\end{abstract}

The fact that Amazonian people seem to be less exposed to HPV, makes it likely that some other risk factors including host lifestyle behaviors and genetic background may be involved in the development of cervical cancer in this population.

KEY WORDS: HPV; Cervical carcinoma; Rural Bolivia; Amazon.

\section{INTRODUCTION}

There is a central etiologic role of human papillomavirus (HPV) infection in the development of cervical intraepithelial neoplasia (CIN) and cervical carcinoma ${ }^{2,430}$. Cervical cancer constitutes a major health problem world-wide, specially in Latin America. In Bolivia it particularly affects women of reproductive age with low-income ${ }^{25}$. It has been estimated that the incidence of cervical cancer in Bolivia lies among the highest in the world. The incidence of cervical cancer in La Paz, the largest city in Bolivia, has been reported to be $53.1 / 100,000^{24}$, and for Oruro and Potosi (two other important cities in the Andean region) 60.9/ 100,000 and $93.5 / 100,000$ respectively $^{23}$. Twenty-five percent of the total number of women's deaths in Bolivia are due to cancer, of which $65 \%$ correspond to cancer of the cervix ${ }^{22}$.

HPV belongs to the family Papovaviridae, non-enveloped closed, circular, double-stranded DNA viruses with a genome size of about 8000 base-pairs. So far, more than 100 different HPV genotypes, defined on the basis of DNA homology, have been identified, of which more than 40 infect the anogenital tract ${ }^{6}$. Infection with certain types of HPV is considered a main risk factor for the development of cervical cancer $^{8,14,18,19,29}$. HPV infection precedes the development of cervical cancer by several years ${ }^{2}$. Case-control studies, case series, and prevalence surveys have shown that HPV DNA can be detected in adequate specimens of cervical cancer in 90 to $100 \%$ of cases.

Since HPV persistence plays a central role in the etiology of cervical cancer, the evaluation of HPV infection among general population is important for surveillance of cervical cancer specially in rural populations such as those in the Bolivian Amazon, where screening coverage is reduced or sometimes inexistent. Although Bolivia bears a high incidence of cervical cancer, little information regarding the prevalence of HPV infection is available. This study aimed to investigate the extent of HPV infection in rural villages of the Bolivian Amazonian lowland.

\section{MATERIALS AND METHODS}

Study region: The Bolivian country is divided into three regions, the Andean Highland, the Central Valley and the Amazonian lowland. This latter region corresponds to $59 \%$ of the total territory. We studied four rural localities in the Amazonian lowland of Bolivia: San Ramón, Caranavi, Palos Blancos, and Rurrenabaque (Fig. 1).

(1) Department of Virology, Faculty of Medicine, Kagoshima University, Kagoshima, Japan.

(2) Instituto Nacional de Laboratorios de Salud, La Paz, Bolivia.

(3) Departamento de Patologia, Hospital General, La Paz, Bolivia.

(4) Hospital de la Mujer, La Paz, Bolivia.

(5) Academia Boliviana de Medicina, La Paz, Bolivia.

(6) Department of Island Medicine, Faculty of Medicine, Kagoshima University, Kagoshima, Japan.

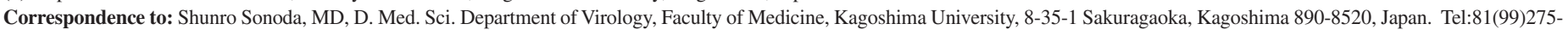
5283, Fax:81(99)265-8164. e-mail: sonoda1@m2.kufm.kagoshima-u.ac.jp 


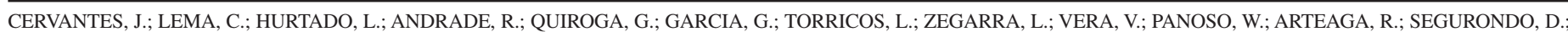
ROMERO, F.; DULON, A.; ASTURIZAGA, D.; HURTADO-GOMEZ, L. \& SONODA, S. - Prevalence of human papillomavirus infection in rural villages of the Bolivian Amazon. Rev. Inst. Med. trop. S. Paulo, 45(3):131-135, 2003.

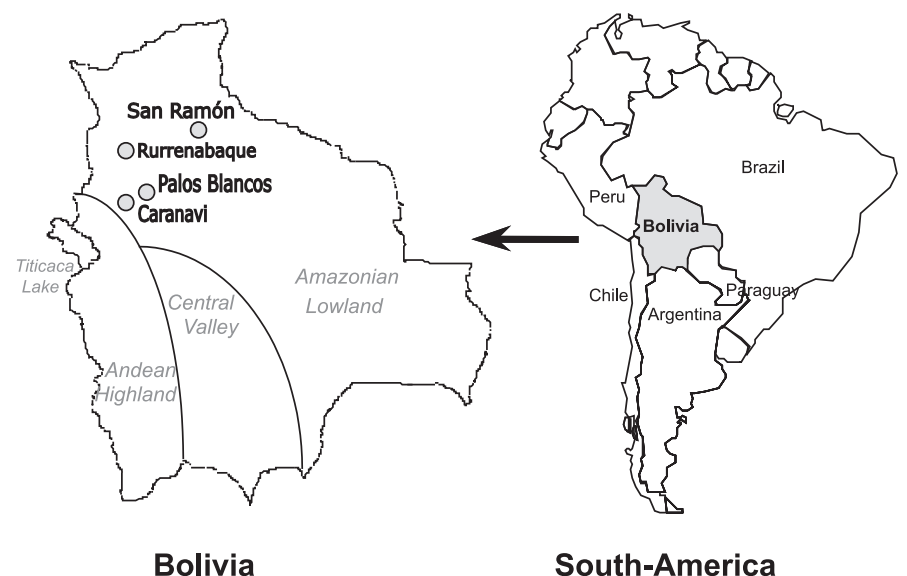

Fig. 1 - Geographic location of the study area

Subjects and samples: We examined a total of 135 healthy women living in four rural localities of the Bolivian Amazon (63 from San Ramón, 51 from Caranavi, 9 from Palos Blancos and 12 from Rurrenabaque). Women were invited to participate by local authorities and medical personnel through local radio station.

After informed consent, pertinent demographic data was obtained through a questionnaire, and participants received a routine gynecological examination. Cervical swabs were collected from all women using a cotton swab, and specimens were preserved in ethanol until their analysis. Briefly, cervical epithelial exfoliated cells were suspended in $1 \mathrm{ml}$ of phosphate-buffered saline (PBS) in a $2 \mathrm{ml}$ Eppendorf tube (Eppendorf, Netheler-Hinz-GmbH, Germany), and then pelleted at $2000 \mathrm{rpm}$ for 10 min. The supernatant was discarded and $1 \mathrm{ml}$ of $99 \%$ ethanol was added to the cell pellet ${ }^{17}$.

$H P V$ detection and genotyping: After DNA extraction by the guanidine-HCl method (SMITEST EX\&D, Sumitomo Metal Industry, Japan), samples were analyzed using a reverse line hybridization protocol that allows discrimination of $27 \mathrm{HPV}$ types ${ }^{9}$. Briefly, after a polymerase chain reaction (PCR) amplification using HPV consensus primers in the L1 gene as well as beta-globin specific primers, the PCR product hybridizes to an array of immobilized oligonucleotide probes, that are then visualized by color development. All reagents were kindly provided by Roche Molecular Systems Inc. (Alameda, CA).

Statistical Analysis: A one-way-ANOVA (analysis of variance) was used to calculate for statistical differences in age, age of first sexual intercourse, number of sexual partners, steady sexual partners, pregnancies, full term pregnancies, and abortions. The Chi-square, or Fisher's exact test where appropriate, was used for comparison of other demographic variables. Tests were run using SPSS (Statistical Package for the Social Sciences) software, version 7.5 (SPSS Inc. 1989-1996).

\section{RESULTS}

Table 1 shows the demographic profile of the women from the four rural localities studied. Almost forty percent of the women had fewer than 6 years of education. The age at first sexual intercourse was in average 17 year-old. Most of the women studied were married and have been pregnant with 5 or more children. The majority of the study participants reported one lifetime sexual partner. More than $78 \%$ of the women were non-smokers (with less than $10 \%$ of the women reporting a history of smoking in some of the villages).

There was a significant statistical difference in the ethnic composition, the distribution of marital status, smoking status, occupation, as well as the number of pregnancies and abortions between the rural localities studied. Other demographic variables like age, educational level, age of first sexual intercourse, and number of sexual partners showed no significant statistical difference.

The prevalence of HPV infection in each locality was: San Ramon $3.2 \%$ (2/63), Rurrenabaque 16.6\% (2/12), Palos Blancos 0\% (0/9) and Caranavi $7.8 \%(4 / 51)$. The overall prevalence was 5.9\% (8/135) (Table 2).

In the four rural localities studied, HPV typing revealed the presence of four low risk HPV genotypes: HPV-6, HPV-11, HPV-66 and MM8 and five high risk genotypes: HPV-26, HPV-39, HPV-51, HPV-52, and HPV-59 (Table 2). No specific HPV type was more frequent than the others. Two cases of dual infection were found in Caranavi and Rurrenabaque HPV-11 and HPV-39; and HPV-59 and MM8, respectively. One case of multiple (triple) infection was found in San Ramon, where HPV-66, HPV-26, and HPV-52 were found in the same sample.

\section{DISCUSSION}

Even though Bolivia is considered an Andean country, 59\% of its territory corresponds to the Amazonian region ${ }^{25}$. Is hard to obtain a value of cervical cancer incidence for the whole country due to limitations in the diagnosis and registration practices, specially in rural areas. Reports from several Bolivian Andean cities, showed very high incidence rates of cervical cancer ${ }^{23,24}$. Although these reports refer to Andean populations, cervical cancer incidence might be also high in the Amazon taking into account some studies done on indigenous women from Brazil ${ }^{3,27}$.

As infection with HPV is the main risk factor for the development of cervical cancer ${ }^{2,30}$, in terms of HPV infection our study population seems to be at low risk for developing cervical cancer. The estimated overall HPV infection prevalence among the studied rural localities was $5.9 \%$. It ranged from 0 to $16.6 \%$ (no infection was found in the village of Palos Blancos, probably due to the small sample size), these values were lower than expected considering the high rates of cervical cancer incidence reported for the country. A study done in rural Costa Rica reported a prevalence of HPV infection of $11 \%{ }^{11}$. The HPV infection prevalence, however ranges from $10 \%$ to $50 \%$ in sexually active women, being thus considered the most common sexually transmitted viral disease $^{10}$.

The low prevalence found, can still be due to a low sensitivity of the method used, as some reports state that HPV infection can vary according to the primers used in the detection ${ }^{28}$. However, we tested the samples with a different HPV detection system, a PCR-RFLP method using primers in the E6-E7 region ${ }^{7}$ and found a similar detection rate (data not shown).

Four low risk (HPV-6, -11, -66 and MM8) $)^{20,21}$, and five high risk 


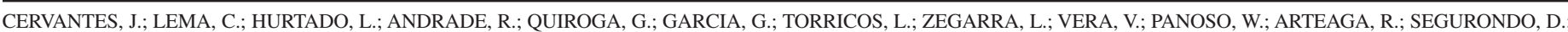

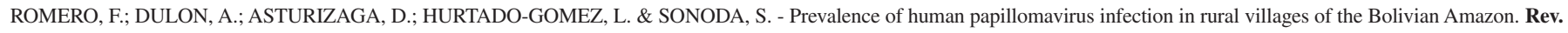
Inst. Med. trop. S. Paulo, 45(3):131-135, 2003.

Table 1

Demographic profile of women from four rural localities in the Bolivian Amazon

\begin{tabular}{|c|c|c|c|c|c|}
\hline \multirow[b]{2}{*}{ Variable } & \multicolumn{4}{|c|}{ Village } & \\
\hline & $\begin{array}{l}\text { San Ramon } \\
\quad(n=63)\end{array}$ & $\begin{array}{c}\text { Caranavi } \\
(\mathrm{n}=51)\end{array}$ & $\begin{array}{l}\text { Palos Blancos } \\
\qquad(\mathrm{n}=9)\end{array}$ & $\begin{array}{l}\text { Rurrenabaque } \\
\qquad(\mathrm{n}=12)\end{array}$ & \\
\hline$\overline{\operatorname{Age}^{\varepsilon}}$ & $36.5[16-71]$ & $34.9[16-65]$ & $38[23-67]$ & $40.1[20-70]$ & $\mathrm{NS}^{\mathrm{a}}$ \\
\hline $\begin{array}{l}\text { Ethnic group }(\%) \\
\text { Aymara } \\
\text { Quechua } \\
\text { Mestizo } \\
\text { Other }\end{array}$ & $\begin{array}{c}2.9 \\
17.6 \\
76 \\
2.9\end{array}$ & $\begin{array}{c}42.4 \\
13 \\
42.4 \\
2.2\end{array}$ & $\begin{array}{c}66.7 \\
4.8 \\
19 \\
9.5\end{array}$ & $\begin{array}{c}4.3 \\
0 \\
0 \\
95.7\end{array}$ & $\mathrm{p}<0.001^{\mathrm{b}}$ \\
\hline $\begin{array}{l}\text { Education }(\%) \\
\text { None } \\
\text { Primary } \\
\text { Secondary or higher }\end{array}$ & $\begin{array}{l}11.8 \\
52.9 \\
35.3\end{array}$ & $\begin{array}{c}8.3 \\
38.5 \\
53.1\end{array}$ & $\begin{array}{l}13.6 \\
27.3 \\
59.1\end{array}$ & $\begin{array}{c}8.3 \\
33.3 \\
58.1\end{array}$ & $\mathrm{NS}^{\mathrm{b}}$ \\
\hline $\begin{array}{l}\text { Marital status }(\%) \\
\text { Married or living as married } \\
\text { Separated/Widowed } \\
\text { Single }\end{array}$ & $\begin{array}{c}94.1 \\
4.4 \\
1.5\end{array}$ & $\begin{array}{c}77.2 \\
17.6 \\
5.9\end{array}$ & $\begin{array}{c}69.6 \\
26.1 \\
0\end{array}$ & $\begin{array}{c}79.2 \\
20.8 \\
6.1\end{array}$ & $\mathrm{p}<0.05^{\mathrm{b}}$ \\
\hline $\begin{array}{l}\text { Smoking status }(\%) \\
\text { Smoker } \\
\text { Non-smoker }\end{array}$ & $\begin{array}{c}9 \\
91\end{array}$ & $\begin{array}{l}20.7 \\
79.3\end{array}$ & $\begin{array}{c}9.1 \\
90.9\end{array}$ & $\begin{array}{l}36.4 \\
63.6\end{array}$ & $\mathrm{p}<0.05^{\mathrm{b}}$ \\
\hline $\begin{array}{l}\text { Age of first sexual intercourse } \\
\text { Number of lifetime sexual partners } \\
\text { Number of steady sexual partners }^{\varepsilon} \\
\text { Number of pregnancies } \\
\text { Number of full term pregnancies }{ }^{\varepsilon} \\
\text { Number of abortions }\end{array}$ & $\begin{array}{c}17.01[13-24] \\
1.57[1-3] \\
1.22[1-3] \\
5.5[1-14] \\
5.03[1-13] \\
0.68[0-6]\end{array}$ & $\begin{array}{l}17.31[10-32] \\
1.97[1-6] \\
1.23[1-3] \\
4.69[1-15] \\
3.45[1-10] \\
1.61[0-12]\end{array}$ & $\begin{array}{c}17.32[14-24] \\
1.79[1-5] \\
1.26[1-5] \\
6.70[2-14] \\
5.90[2-13] \\
1.41[0-8]\end{array}$ & $\begin{array}{l}16.71[12-22] \\
1.75[1-4] \\
1.21[1-4] \\
6.21[1-16] \\
5.29[1-16] \\
1.37[0-3]\end{array}$ & $\begin{aligned} & N S^{\mathrm{a}} \\
& N S^{\mathrm{a}} \\
& N S^{\mathrm{a}} \\
\mathrm{p} & <0.05^{\mathrm{a}} \\
\mathrm{p} & <0.01^{\mathrm{a}} \\
\mathrm{p} & <0.01^{\mathrm{a}}\end{aligned}$ \\
\hline $\begin{array}{l}\text { Occupation }(\%) \\
\text { Housewife } \\
\text { Merchant } \\
\text { Farmer } \\
\text { Professional } \\
\text { Others }\end{array}$ & $\begin{array}{c}73.5 \\
16.2 \\
1.5 \\
4.4 \\
4.4\end{array}$ & $\begin{array}{c}46.8 \\
24.5 \\
9.6 \\
8.5 \\
10.6\end{array}$ & $\begin{array}{c}45.5 \\
13.6 \\
18.2 \\
9.1 \\
13.6\end{array}$ & $\begin{array}{c}70.8 \\
0 \\
4.2 \\
16.7 \\
8.3\end{array}$ & $\mathrm{p}<0.001^{\mathrm{b}}$ \\
\hline
\end{tabular}

${ }^{\varepsilon}$ mean [range]; NS: Non significant; ${ }^{\text {a }}$ One way ANOVA; ${ }^{\mathrm{b}}$ Chi square test (or Fisher exact test, where appropriate)

Table 2

Prevalence of HPV infection in four rural villages of the Bolivian Amazon

\begin{tabular}{|c|c|c|c|c|c|}
\hline Village & $\mathrm{n}$ & $\begin{array}{l}\text { HPV Positive } \\
\text { subjects }\end{array}$ & $\begin{array}{l}\text { HPV } \\
\text { Types }\end{array}$ & $\begin{array}{c}\text { HPV } \\
\text { Multiple infection }\end{array}$ & $\begin{array}{l}\text { HPV infection } \\
\text { Prevalence }(\%)\end{array}$ \\
\hline San Ramón & 63 & 2 & $\begin{array}{l}\text { HPV-16 } \\
\text { HPV-26 } \\
\text { HPV-52 } \\
\text { HPV-66 }\end{array}$ & HPV-16/-26/52 & 3.17 \\
\hline Caranavi & 51 & 4 & $\begin{array}{l}\text { HPV-11 } \\
\text { HPV-39 } \\
\text { HPV-51 }\end{array}$ & HPV-11/39 & 7.84 \\
\hline Palos Blancos & 9 & 0 & & & 0 \\
\hline Rurrenabaque & 12 & 2 & $\begin{array}{c}\text { HPV-6 } \\
\text { HPV-59 } \\
\text { HPV-MM8 }\end{array}$ & HPV-59/MM8 & 16.6 \\
\hline
\end{tabular}




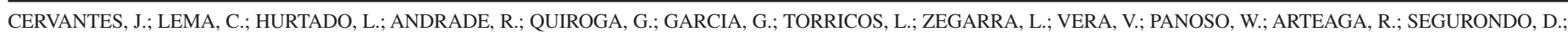
ROMERO, F.; DULON, A.; ASTURIZAGA, D.; HURTADO-GOMEZ, L. \& SONODA, S. - Prevalence of human papillomavirus infection in rural villages of the Bolivian Amazon. Rev. Inst. Med. trop. S. Paulo, 45(3):131-135, 2003.

HPV types (HPV-26, -39, - 51, -52, and -59$)^{9}$ were found among the studied women. Eventhough reported as a "low-risk" type, HPV-66 has been found present in cervical cancer ${ }^{11}$ and has been included as a high risk in a recent review ${ }^{30}$. Two cases of dual infection, as well as one case of triple infection were detected among the studied women. We must pay attention to this issue as multiple infection with different HPV types may have antagonistic or sometimes synergistic effect with respect to carcinogenesis $^{26}$. It seems to be common to find a wide variety of HPV types in healthy women ${ }^{11,12,15}$. The classical high risk HPV-16 and HPV18 being uncommon in healthy women has been reported also in rural Latin America ${ }^{11}$.

HPV DNA point prevalence reflects not only recent exposures but also a subset of old exposures that have failed to induce an appropriate cellular immunity and have become persistent ${ }^{5}$. These studies are very informative in terms of evaluating the risk of developing cervical cancer caused by the well known high risk HPVs as well as new emergent viral genotypes.

Potential differences between rural and urban women that could help to explain a low HPV infection prevalence were pointed out by our group $^{17}$. The relative isolation of the Amazonian cities, compared to the more populated Andean cities, may have halted to some extent the introduction of HPV to this region. If so we would expect very few HPV types to be found, however we observed a quite broad type distribution in just a few infected cases. Even though the country is divided into three well defined regions, during the last decades important migratory movements from the country side to the cities have been observed, making it difficult to clearly establish a rural-urban differentiation on an ethnic and cultural basis ${ }^{25}$.

Most of the studied women were married, monogamous, with less than two life-time sexual partners, fertile housewives (Table 1). A relative absence of risk factors for HPV transmission is a plausible explanation for the low prevalence found. The role of other risk factors, including lifestyle behaviors and genetic background, should be further investigated. Specially the question whether some ethnic groups are more susceptible to specific HPV types, or if some ethnic group has reduced cell immunity to specific HPV types, should be studied. Since immunity is genetically determined, ethnic differences may explain why some women have different levels of susceptibility for specific HPV infection or lower immune response. Variation of cofactors of HPV infection due to ethnicity have been already reported ${ }^{13}$, and it has been observed that Hispanic women with HPV infection have a higher risk for cervical dysplasia compared to non Hispanic white women ${ }^{1}$.

The lack of access to medical care and cancer screening in remote areas, may help to explain the high incidence of cervical cancer in Bolivia. Although our study subjects were healthy women, cytology showed in a great percentage of them reactive changes associated with inflammation. A similar figure has been reported in some Brazilian Amazonian women $^{3,27}$. Detection and treatment of the premalignant lesions is the basis for Papanicolaou (Pap) smear screening, which has been partly responsible for the decline in the incidence of cervical cancer in countries like the United States in the last two decades ${ }^{16}$. Cervical cancer should be seen as a preventable disease ${ }^{6}$. Until the advent of effective and accessible HPV vaccines, cervical cancer screening programs should be strengthened specially in South American countries.

\section{RESUMO}

\section{Prevalência da infecção pelo papilomavirus humano nas aldeias rurais do Amazonas Boliviano}

O câncer cervical constitui problema de saúde da maior importância nos países em desenvolvimento tais como a Bolívia. O papel de certos genótipos de papilomavirus humano (HPVs) na patologia do câncer cervical está bem estabelecido. A prevalência da infecção pelo HPV nas mulheres sexualmente ativas varia amplamente. Contudo, as informações existentes acerca da infecção pelo HPV na Bolivia são muito escassas, especialmente nas zonas rurais, nomeadamente na região amazônica do país.

Foram estudadas 135 mulheres saudáveis, residentes em quatro localidades do Amazonas Boliviano. Foi detectada a presença de HPV no DNA extraído de esfregaços cervicais, utilizando o método de hibridização em linha reversa. A prevalência da infecção por HVP, encontrada nas localidades rurais, foi de 5,9\% (variação entre 0-16,6\%). Estes valores foram inesperadamente baixos, uma vez que a Bolívia é um país com alta incidência de câncer cervical. $O$ fato da população do Amazonas parecer estar menos exposta ao HPV leva-nos a pensar que outros fatores de risco, inclusive estilos de vida e fatores genéticos, poderiam ter alguma relevância no desenvolvimento do câncer cervical nesta população.

\section{ACKNOWLEDGEMENTS}

We express our deep thanks to the Bolivian government and local authorities for their generous collaboration.

\section{REFERENCES}

1. BECKER, T.M.; WHEELER, C.M.; KEY, C.R. \& SAMET, J.M. - Cervical cancer incidence and mortality in New Mexico's Hispanics, American Indians, and nonHispanic whites. West. J. Med., 156: 376-379, 1992

2. BOSCH, F.X.; LORINCZ, A.; MUNOZ, N.; MEIJER, C.J. \& SHAH, K.V. - The causal relation between human papillomavirus and cervical cancer. J. clin. Path., 55: 244$265,2002$.

3. BRITO, E.B.; MENEZES, R.C.; MARTINS, S.J.; BASTOS, M.G. \& SOUSA, A. Preliminary study on low-trait genital infection and cervical epithelial dysplasia in women from the Parakana tribe of South America. Rev. Ass. méd. bras., 42:11-15, 1996.

4. CHICHAREON, S.; HERRERO, R.; MUNOZ, N. et al. - Risk factors for cervical cancer in Thailand: a case-control study. J. nat. Cancer Inst., 90: 50-57, 1998.

5. DILLNER, J. - Trends over time in the incidence of cervical neoplasia in comparison to trends over time in human papillomavirus infection. J. clin. Virol., 19: 7-23, 2000.

6. FRANCO, E.L.; DUARTE-FRANCO, E. \& FERENCZY, A. - Cervical cancer: epidemiology, prevention and the role of human papillomavirus infection. Canad. Med. Ass. J., 164: 1017-1025, 2001

7. FUJINAGA, Y.; SHIMADA, M.; OKAZAWA, K. et al. - Simultaneous detection and typing of genital human papillomavirus DNA using the polymerase chain reaction. J. gen. Virol., 72: 1039-1044, 1991.

8. GAARENSTROOM, K.N.; MELKERT, P.; WALBOOMERS, J.M. et al. - Human papillomavirus DNA and genotypes: prognostic factors for progression of cervical intraepithelial neoplasia. Int. J. gynec. Cancer, 4: 73-78, 1994. 


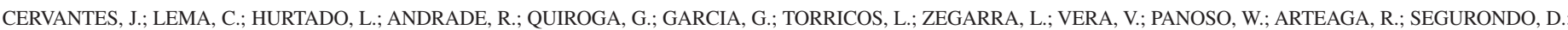
ROMERO, F.; DULON, A.; ASTURIZAGA, D.; HURTADO-GOMEZ, L. \& SONODA, S. - Prevalence of human papillomavirus infection in rural villages of the Bolivian Amazon. Rev. Inst. Med. trop. S. Paulo, 45(3):131-135, 2003.

9. GRAVITT, P.E.; PEYTON, C.L.; APPLE, R.J. \& WHEELER, C.M. - Genotyping of 27 human papillomavirus types by using L1 consensus PCR products by a singlehybridization, reverse line blot detection method. J. clin. Microbiol., 36: 3020-3027, 1998

10. HAGENSEE, M.E. - Infection with human papillomavirus: update on epidemiology, diagnosis, and treatment. Curr. infect. Dis. Rep., 2: 18-24, 2000.

11. HERRERO, R.; HILDESHEIM, A.; BRATTI, C. et al. - Population-based study of human papillomavirus infection and cervical neoplasia in rural Costa Rica. J. nat. Cancer Inst., 92: 464-474, 2000 .

12. HILDESHEIM, A.; SCHIFFMAN, M.H.; GRAVITT, P.E. et al. - Persistence of typespecific human papillomavirus infection among cytologically normal women. J. infect. Dis., 169: 235-240, 1994.

13. KENNEY, J.W. - Ethnic differences in risk factors associated with genital human papillomavirus infections. J. Advanc. Nurs., 23: 1221-1227, 1996.

14. KOUTSKY, L.A.; HOLMES, K.K.; CRITCHLOW, C.W. et al. - A cohort study of the risk of cervical intraepithelial neoplasia grade 2 or 3 in relation to papillomavirus infection. N. Engl. J. Med., 327: 1272-1278, 1992.

15. LAZCANO-PONCE, E.; HERRERO, R.; MUNOZ, N. et al. - Epidemiology of HPV infection among Mexican women with normal cervical cytology. Int. J. Cancer, 91: 412-420, 2001.

16. LAWSON, H.W.; LEE, N.C.; THAMES, S.F.; HENSON, R. \& MILLER, D.S. - Cervical cancer screening among low-income women: results of a national screening program, 1991-1995. Obstet. and Gynec., 92: 745-752, 1998.

17. LEMA, C.H.; HURTADO, L.V.; SEGURONDO, D. et al. - Human papillomavirus infection among Bolivian Amazonian women. Asian Pacific J. Cancer Prevent., 2: 135-141, 2001.

18. LORINCZ, A.T.; TEMPLE, G.F.; KURMAN, R.J.; JENSON, A.B. \& LANCASTER, W.D. - Oncogenic association of specific human papillomavirus types with cervical neoplasia. J. nat. Cancer Inst., 79: 671-677, 1987.

19. LORINCZ, A.T.; REID, R.; JENSON, A.B. et al. - Human papillomavirus infection of the cervix: relative risk associations of 15 common anogenital types. Obstet. and Gynec., 79: 328-337, 1992.
20. MANOS, M.M.; WALDMAN, J.; ZHANG, T.Y. et al. - Epidemiology and partial nucleotide sequence of four novel genital human papillomaviruses. J. infect. Dis. 170: 1096-1099, 1994

21. MEYER, T.; ARNDT, R.; CHRISTOPHERS, E. et al. - Association of rare human papillomavirus types with genital premalignant and malignant lesions. J. infect. Dis. 178: $252-255,1998$

22. PROGRAMA NACIONAL DE SALUD SEXUAL Y REPRODUCTIVA 1999-2002. Bolivia, Ministerio de Salud y Previsión Social; Unidad Nacional de Atención a las Personas, 2002

23. RÍOS DALENZ, J.; MONTAÑO, S.; GUERRA, C. \& LAVADENZ, F. - El cancer en la zona andina de Bolivia. Patología, 29: 123-127, 1991.

24. RÍOS DALENZ, J.; CASABLANCA, S.; SALAZAR, R. et al. - El cancer en una población urbana de la altura. Acta Andina, 4: 65-70, 1995.

25. RÍOS DALENZ, J. \& CASTRO, M.D. - Evaluación de la situación del cancer de cuello uterino en Bolivia. Revisión Bibliografica. OPS/OMS Ministerio de Salud y Previsión Social Engender Health, Formerly AVSC International, 2001.

26. SILINS, I.; WANG, Z.; AVALL-LUNDQVIST, E. et al. - Serological evidence for protection by human papillomavirus (HPV) type 6 infection against HPV type 16 cervical carcinogenesis. J. gen. Virol., 80: 2931-2936, 1999.

27. TABORDA, W.C.; FERREIRA, S.C.; RODRIGUES, D.; STAVALE, J.N. \& BARUZZI, R.G. - Cervical cancer screening among indigenous women in the Xingu Indian Reservation, central Brazil. Rev. panamer. Salud publ., 7: 92-96, 2000.

28. TERRIS, M.K. \& PEEHL, D.M. - Human papillomavirus detection by polymerase chain reaction in benign and malignant prostate tissue is dependent on the primer set utilized Urology, 50: 150-156, 1997

29. ZUR HAUSEN, H. - Human pathogenic papillomaviruses. In: Molecular pathogenesis of cancer of the cervix and its causation by specific human papillomavirus types. Current Topics in Microbiology and Immunology CTMI186. Berlin, SpringerVerlag, 1994. p.131-156.

30. ZUR HAUSEN, H. - Papillomaviruses and cancer: from basic studies to clinical application. Nat. Rev. Cancer, 2: 342-350, 2002

Received: 6 March 2003

Accepted: 15 April 2003 